\title{
Library Orientation for Business Students: A Case Study
}

In 1978, Louisiana State University"s Middleton Library underwent a major public service reorganization eliminating separate subject divisions, with one exception-the Government Documents Department. While the planning of this change was taking place, the College of Business Administration supported the establishment of a separate business reference service in the Middleton Library. To achieve this request, the Library Administration decided to merge the business reference collection with the Government Documents Department to form a new Business Administration/Government Documents Department. This move proved to be very logical since a substantial portion of business questions are answered from government documents and the staff of the Government Documents Department were very interested in assuming the additional responsibility.

II ith a well-established reputation for excellent public service, the staff of the Business Administration/Government Documents Department tackled the new responsibility and began to serve the information needs of the College of Business Administration. As the enrollment in the college continued to increase at a substantial rate each vear, it became a real necessity to develop a program of specialized library instruction for business students.

With a staff of four librarians and over 3,000 business students, it was decided that individual classroom lectures in each business course were not feasible: an alternative had to be found. The logical place to reach new business students seemed to be through a course called " Business Communication." which is required of all business majors. The possibility of library staff using this course to teach basic business research skills was explored with the faculty of the Business Conmunication and Office Systems Department. They were eager to cooperate with the idea and said they would use whatever was devised.

In 1981 . it was decided to explore the possibility of producing a videocassette to be used as an introduction to the business resources of the library. A set of objectives was written and the university"s Instructional Resources Center contacted for assistance. The objectives of the project were to inform students of the library's business resources and services. to train them in the use of selected business and government documents reference materials useful in completing coursc assignments, and to impress upon them that libraries are information centers which will be useful during their business careers.

After several enthusiastic meetings with a representative from the IRC, it was agreed to pursue the videocassette approach and an outline of how to complete the project was prepared. The next step involved writing and rewriting a script over a three-week period. After the library staff and the IRC representative agreed on the contents and wording of the script, a shooting schedule was prepared. Two days were spent filming scenes in the library. in offices. and at the local airport. After nearly three months of work, the finished videocassette was ready for use.

"Business Information Sources." as the videocassette was called, introduces students to the business resources of the Middleton Library during its 26 minutes. It opens with a commercial jetliner landing and the statement "the world of business is $d y$ namic and everchanging." It continues with general information on library organization and use. a discussion of how to use several business periodical indexes. sources of company information. procedures to follow to locate U.S. government publications relating to business, and conclides with a demonstration of computerized information retrieval. Prior to using the videocassette. library staff met with the instructors of the "Business Communication" sections to explain how to use the videocassette and how to obtain videoplavers from the IRC. Each instructor was given a tour of the Business Administration/Government Documents Department to prepare them for questions the students might ask about the library.

During the one and one-half vears the videocassette has been in existence, over 3.500 students at LSU have seen it. In addition to using it in the sections of "Business Communication" and other business courses, several other departments have used it. including Books and Libraries. Home Economics. Journalism. Speech. Library Science, etc.

To reinforce the business information sources covered in the videocassette, as series of librar. guides under the general series title "Business Research Guides" was prepared. These guides cover the major sources useful in locating company and industry information, computerized access to business information. financial and operating ratios. business periodicals and indexes, bibliographies and research guides in business, and sources of economic statistics. The guides to company and indus 
try information are included in the syllabus prepared by the Business Communications Department and distributed to all students taking "Business Communication." The guides are also available in the Business Administration/Government Documents Department and in the Reading Room in the College of Business Administration. They have proved to be useful in numerous other classes and have saved considerable staff time. Students using the guides may help themselves in most instances.

Orienting undergraduates in business to the library is a relatively easy task: graduate students in business are another matter. They are more diverse in their information needs and require a higher level of library support. Many business graduate students are unfamiliar with business research materials because they come from other disciplines. Doing library research is often a frustrating experience because of their unfamiliarity with business information sources.

Realizing this frustration, the staff of the Business Administration/Government Documents Department decided to initiate a library orientation program for graduate business students. The orientations are planned around a two-hour block of time and offered on a weekday morning, a weekday evening, and a Saturday morning.

The orientations are publicized by sending memoranda to the deans and chairmen of all the departments in the College of Business Administration, placing posters in the Business Administration/Government Documents Department and in the College of Business Reading Room. and having announcements appear in the campus newsletter, "FY'I," and the daily newspaper. "The Reveille," The most effective method of publicity seems to be simply word of mouth. Students are asked to call for a reservation on their preferred dav. It should be noted that these orient ations are not held in conjunction with any class and students come during their own free time.

The orientations are planned to cover as much information as possible during the two-hour period. The sessions begin with a general introduction to the organization and service points in the $\mathrm{l}$ brary. Suggestions on how to more effectively use the card catalog are given. Since periodical indexes are one of the most important access tools to business information, the major periodical indexes are discussed as well as procedures for locating periodicals in the Middleton Library: Research guides and bibliographies are presented as aids to locating information beyond the card catalog and periodical indexes. Considerable time is spent on statistical sources and how to locate and use government documents. The sessions are concluded with a demonstration of bibliographic and non-bibliographic database searching.

These sessions for graduate business students seem to have inmediate results. A marked difference may be noted in use of the library by students attending the sessions versus those still trving to fumble their way through the information maze. They also allow for the development of a closer working relationship between the librarians and students.

Library instruction at LSU is also offered through a one-credit course called "Introduction to the Use of the Library" and through numerous classroom presentations made by reference librarians.-Milton G. Ternherg. Middleton Library, Louisiana State University. Baton Rouge.

\section{BI Exhibit Update}

\author{
Carolyn Kirkendall \\ Project LOEX
}

In the past two months, many requests to borrow the BI Liaison Project display have been received, and many more opportunities to exhibit the module have been identified. I'm also happy to report about sev'eral presentations at conventions and association meetings:

Marilyn Lutzker, Head of Reader Services at the John Jay College Library, presented a paper on "Use of Primary Resources for Undergraduate Tern Papers in Criminal Justice" at the Academy of Criminal Justice Science's annual conference in February at San Antonio. A Roundtable on Criminal Justice Research Resources has been formed within the Academy:

Negotiations are progressing for sponsoring a drop-in session using the ACRL BI Liaison Project exhibit at the Fall meeting in Toronto of the American Council on Education. Our proposal was not accepted for program agenda.

The Program of the National Conference on Teaching Excellence, sponsored by the NISOD at the University of Texas at Austin, will include a presentation by John Kupersmith, Assistant for Public Services Programs at the General Libraries of UT-Austin. The ACRL BI Liaison Project exhibit will also be on display at this May 24-27 Conference.

Peggy: Toifel of the University of West Florida Library participated in the program of the Council on Social W'ork Education's annual meeting last month in Fort Worth, and her presentation was accompanied by the exhibit.

The exhibit was also part of the Idea Mart Booths. a feature of the recent convention of the American Association of Higher Education in W'ashington. D.C. In .May. promotional literature 